\title{
Twin Deficits: Evidence From Portugal, Italy, Spain and Greece
}

Since the mid-2000s, internal and external imbalances have increased in many EU countries. This contributed to the debate over whether government budget deficits affect current account deficits, known as twin deficits hypothesis. It implies that public debt is actually a burden for future taxpayers and thus a dangerous way for budget financing. Therefore, the fiscal measures implemented by policymakers may also affect the current account. This article tests the twin deficits hypothesis for Portugal, Italy, Spain and Greece for the period 1999-2017. The empirical analysis presented in the article finds evidence that strongly supports this hypothesis only for Italy and Greece. For Portugal and Spain, however, the evidence is quite weak.

Since the 1980s, a debate has ensued over whether government budget deficits affect the current account deficits. This debate, known as the twin deficits hypothesis (TDH), is supported by Keynesian economists and implies that an increase in a government's budget deficit (BD) will increase the current account deficit (CAD). On the other hand, the Ricardian Equivalence Hypothesis (REH), first introduced by Barro (1974), postulates that BD and CAD are not related: a BD will be totally offset by changes in savings and thus will not affect the current account. According to REH, the increase in government spending leads to more debt and therefore households increase their savings as they expect higher future taxes for offsetting this debt. However, empirical studies regarding $\mathrm{REH}$ provide mixed results.

The relationship between $B D$ and $C A D$ is crucial as internal and external imbalances in many EU countries are increasing. If the TDH holds for a country, it implies that the $\mathrm{REH}$ is not valid and the public debt is actually a burden for future taxpayers. Consequently, it poses a problem for budget financing and may even lead to a future fiscal cri-

(C) The Author(s) 2020. Open Access: This article is distributed under the terms of the Creative Commons Attribution 4.0 International License (https://creativecommons.org/licenses/by/4.0/).

Open Access funding provided by ZBW - Leibniz Information Centre for Economics.

Konstantinos P. Panousis, Cosmote Mobile Telecommunications S.A., Athens; and Hellenic Open University, Patra, Greece.

Minoas Koukouritakis, University of Crete, Rethymnon; and Hellenic Open University, Patra, Greece. sis. This is, of course, quite crucial for policymakers, as the fiscal measures they implement for reducing BD may also affect the current account.

This paper first provides an extensive literature review regarding the validity of the TDH, focusing on Portugal, Italy, Greece and Spain. Subsequently, the basic theoretical framework of the TDH and REH is presented, followed by the econometric methodology and the empirical results.

There is no strong evidence to support the TDH for Portugal, which implies that an increase in BD will be totally offset by changes in private savings and, thus, there will be no impact on CAD. In contrast, there is evidence in favour of the TDH for Italy, which implies that the policy measures for improving current accounts could improve public finances. For Greece, a BD increase is partly offset by an increase in private savings and thus the CAD is widening. The results support the TDH partially and imply the necessity for implementing alternative policies, such as promoting investments in new technology, innovations in exporting sectors and tax cuts on selected industries. Finally, for Spain, there is no evidence that the CAD and the $\mathrm{BD}$ are moving together in the long run.

\section{Literature review}

The alleged link between the budget balance and the current account balance caused an intense debate among economists, especially in the 1980s and 1990s. The empirical results regarding the validity of the TDH are mixed and depend on the macroeconomic conditions of the countries under consideration. Barro (1974) claimed that there is no correlation between BD and CAD and argued that present borrowing would be matched by increased bequest to future generations in order to pay higher future 
taxes for servicing the debt. This was in direct response to Blinder and Solow (1973), who imply that the long-term implications of government borrowing would be compensated by the wealth effect.

Most empirical studies have been focused on the US, but the literature is quite extensive and includes research on several developed and developing countries. Among others, Bernheim (1987) analysed the relationship between changes in consumption and changes in deficits in the US and concluded that consumers' behaviour is more aligned with REH. Kearney and Monadjemi (1990) found evidence of a temporary twin deficits realtionship between fiscal policy and performance on the current account. Their evidence also implied that fiscal expansions improve current accounts as the economy adjusts towards its long-run equilibrium, while the twin deficits realtionship depends on the government's financing decision. Enders and Lee (1990) identified some patterns in the recent US data that appear to be inconsistent with the REH, and Abell (1990) showed that $B D$ affects $C A D$ through the transmission mechanisms of interest rates and exchange rates. Similar results were obtained from Bachman (1992), whose evidence supported the validity of the TDH. However, Feldstein (1992) argued that it is wrong to generalise from the US experience to conclude that $\mathrm{BD}$ and $\mathrm{CAD}$ are two sides of the same coin because the division between them depends mainly on the external economic environment.

Normandin (1999) analysed the responses of CAD to an increase of BD for Canada and the US and showed that the stochastic properties of the $\mathrm{BD}$ are crucial for testing the TDH. Khalid and Guan (1999) used a sample of developing and developed countries and found evidence that supports the TDH only for the developing countries. The findings of Piersanti (2000) strongly supported the view that CADs have been associated with large expected future BDs for most industrial countries, whereas Chinn and Prasad (2000) showed that government budget balances are positively correlated with current account balances and with initial stocks of net foreign assets. Leachman and Francis (2002) explored the TDH for the US and found no evidence of short-run correlations between government deficits and external deficits, while Gale and Orszag (2003) showed that long-term BDs reduce national savings and impose substantial long-run costs on the economy. If an increase in the BD is not fully offset by an increase in private savings, it will lead to some combination of reduced domestic investments and an expanded CAD.

Kouassi et al. (2004) analysed a sample of twenty developed and developing countries and found evidence that supports the TDH only for some developing countries. Reitschuler and Crespo Cuaresma (2004) tested the REH for
26 OECD countries and found that it cannot be rejected for ten countries, of which nine are European. Cavallo (2005) identified that an increase in government expenditure on final goods produces a sizeable deterioration in the current account balance, while Erceg et al. (2005) showed that changes in fiscal policy have fairly small effects on the US trade balance, irrespective of whether the source is a spending increase or a tax cut. The results of Bartolini and Lahiri (2006) supported the TDH, and Mukhtar et al. (2007) found evidence of a long-run bi-directional relationship between the two deficits in Pakistan. Kim and Roubini (2008) suggested that an expansionary fiscal policy shock improved the current account and depreciated the real exchange rate in the US. Afonso (2008) tested the debt neutrality hypothesis for the EU countries and showed that after the 1990s, the REH could not be rejected.

Nickel and Vansteenkiste (2008) showed that for countries with debt-to-GDP ratios up to $90 \%$, the relationship between the government budget balance and the current account is positive, while for countries with high debt this relationship becomes negative. In other words, countries with high-debt households tend to become Ricardian. Kosteletou (2013) confirmed the TDH for the countries of the southern eurozone. She also found that fiscal policies of the eurozone countries with surpluses have a positive influence on the current account of southern eurozone countries. Finally, Forte and Magazzino (2013) analysed 33 European countries and showed that a long-lasting and robust $\mathrm{BD}$ generates a $\mathrm{CAD}$.

The cases of Portugal, Italy, Greece and Spain

Greece, Italy, Portugal and Spain suffer from long-lasting CADs, whereas BDs became a problem only after the 2009 crisis. For Greece and Portugal, insolvency is the problem: their economies suffer from low national savings and depend on high capital inflows. For Spain, illiquidity is the problem: national savings are high and the crisis was due to financial activity expansion. In Italy, the problem is different: its economy deals with high savings, small foreign imbalances and a conservative financial sector.

Cardoso and Doménech (2011) studied Spain and found that the negative correlation between the government budget balance and the current account, or twin divergence, cannot be explained by the large fiscal stimulus implemented during the crisis. This evidence is mainly attributed to output loss, deleveraging and uncertainty. Magazzino (2012) analysed the linkages between CAD and BD in Italy and showed that CAD affects BD only in the short run. His results also imply that by correcting external imbalances, the Italian government could improve public finances. Akdoğan and Geldi (2013) investigated 
the current account in seven selected EU members, including Greece, Italy, Portugal and Spain. They found a long-run relationship between the current account and its determinants such as the real exchange rate, interest rate and the budget deficit, but their evidence in favour of TDH was weak. Also, Deltoro and Carmarero (2015) found evidence that validated the REH for Greece and Portugal, and supported the TDH for Italy and Spain, in which BDs cause CADs.

For Greece, its increasing debt was primarily the result of the growing BD triggered by the euro appreciation and the subsequent loss of competitiveness, as well as the extensive tax evasion. This loss of external competitiveness also led to a persistent CAD. As a result, economic activity slowed and tax revenues declined. On the other hand, the government increased public expenditures to offset the decline in demand. Thus, the BD increased and so did public debt. The increased demand for funds from the public sector led to an increase in interest rates, which depressed economic activity again. Since 2007, public expenditure and thus BD continued to increase.

Vamvoukas (1999) empirically tested the validity of TDH and REH in the case of Greece and showed that BD has short- and long-run positive causal effects on CAD. Thus, policy measures that are able to reduce BD may also contribute to the reduction of CAD. Also, Bitzis et al. (2008) showed that the BD does not seem to have had a strong impact on the CAD. Antzoulatos (2011) provided empirical evidence for the assessment that the root cause of the Greek crisis is the loss of competitiveness, as manifested by the increasing CAD, and not the BD. In fact, the empirical evidence indicates that current account deterioration is followed by budget deterioration. Kalou and Paleologou (2012) showed that the two deficits were positively linked and the causality was running from CAD to BD. Their findings also imply that domestic developments are dictated by the foreign balance only to a certain extent. It is more likely that these are also caused by the existence of a large parallel economic sector. Thus, tax reforms for reducing tax evasion and structural reforms in the labour and capital markets are imperative.

To summarise, the REH argues that BD and CAD are not correlated, whereas the Keynesian proposition confirms the existence of a positive relationship between them, where BD causes CAD. However, the empirical literature presented above is inconclusive. In several cases it supports the conventional Keynesian proposition that BD causes CAD, while in other cases there is evidence of reverse causality or bi-directional causality. Moreover, a few studies provide evidence that support the REH and imply that $\mathrm{BD}$ and $\mathrm{CAD}$ are uncorrelated.

\section{Theory and econometric methodology}

\section{Twin deficits hypothesis}

The TDH states that an increase in BD will cause an increase in CAD. The current account $(C A)$ records the transactions of a country with the rest of the world. A current account deficit $(C A<0)$ implies that a country is a net importer. Recall that the gross national income $(Y)$ is given by:

$$
Y=C+I+G+C A,
$$

where $C$ is private consumption, I stands for investment, and $G$ is government consumption. To evaluate the $T D H$, we decompose total national savings $(S)$ into public savings $\left(S_{G}\right)$

$$
S_{G}=T-G,
$$

where $T$ represents taxes, and private savings $\left(S_{p}\right)$

$$
S_{P}=Y-T-C
$$

Therefore:

$$
\begin{gathered}
Y=C+I+G+C A \Leftrightarrow C A=Y-C-G-I \Leftrightarrow C A=(Y-T-C)+(T-G)-I \Leftrightarrow \\
C A=S_{p}+S_{g}-I \Leftrightarrow C A=S-I .
\end{gathered}
$$

CAD is therefore equal to the excess of domestic investment over savings: when a country's investment exceeds its savings the difference must be financed from abroad. In principle, less developed countries that are catching up will generally feature CADs, while advanced economies will have surpluses. From equation (4) we get:

$$
C A=S_{p}+S_{g}-I \Leftrightarrow C A=\left(S_{p}-I\right)+(T-G)
$$

Equation (5) implies that if domestic investment is entirely financed by private savings $\left(S_{P} \approx l\right)$, then the current account and government balance must move together (i.e. they are "twins"). However, in most cases, the public sector is financed partly by domestic and partly by international financial markets. Thus, an increase in BD will cause an increase in CAD.

\section{Ricardian equivalence hypothesis}

The REH was firstly introduced by Barro (1974) and its main assumption is that under specific conditions, changes in taxes would have no effect on consumer spending. A tax decrease will lead to an identical increase in savings. Also, the REH indicates that the time path of taxes has no 
Figure 1

Current account deficit and budget deficit as percentage of GDP in selected countries
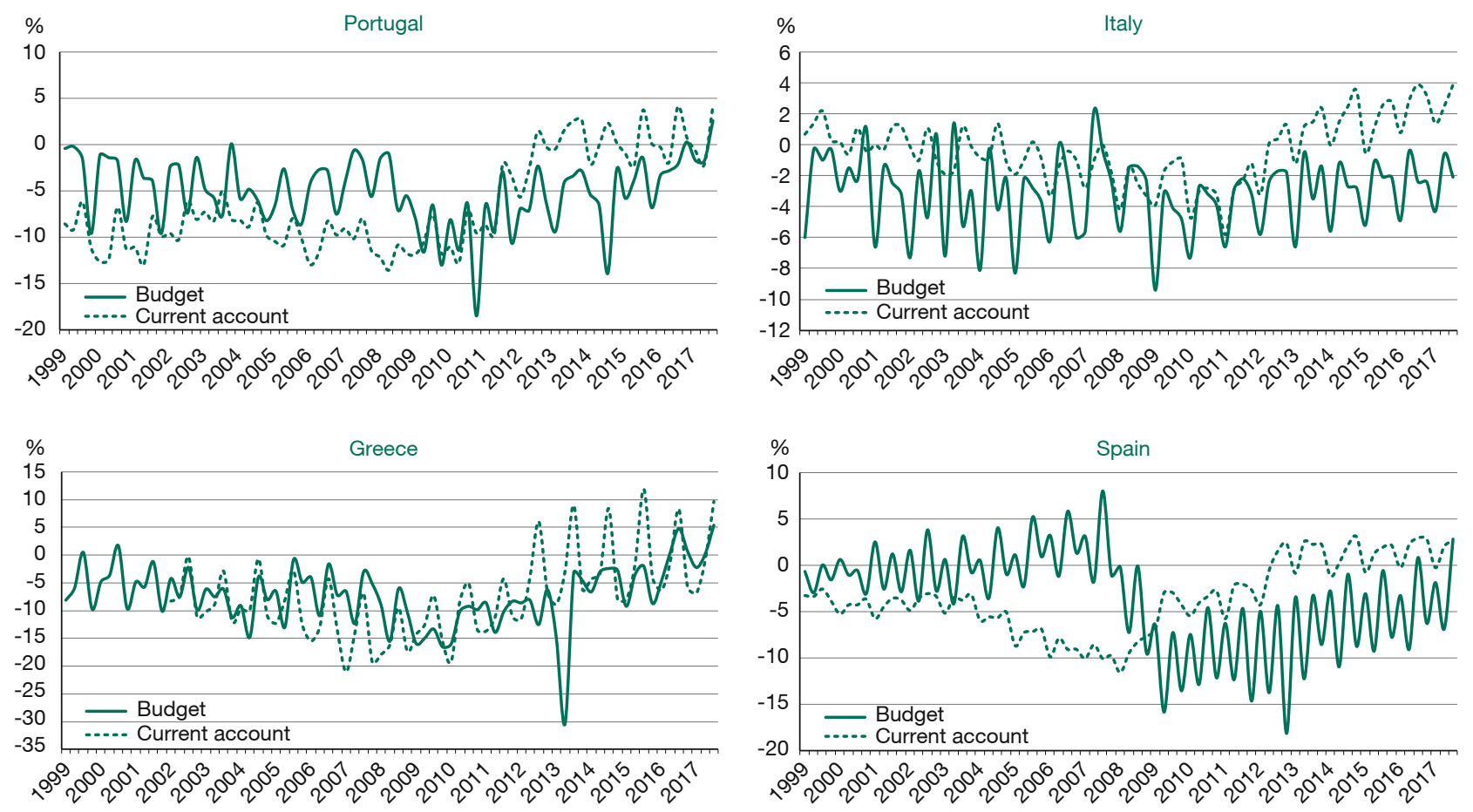

Source: Authors' own elaboration based on Eurostat data.

effect on the households' budget constraint as long as the present value of taxes remains unchanged. Government financing decisions may influence private savings, private investment and current account. As government increases spending, it also increases public debt. Thus, households increase their savings as they expect higher future taxes for offsetting this debt. It follows that if the REH is valid, countries with high levels of debt should also have comparatively higher levels of household savings. However, the REH assumes the existence of perfect capital markets and the ability for individuals to borrow and save whenever they want. But in real world, households may not be able to borrow against future income because of imperfections in financial markets. Additionally, the REH assumes that individuals are willing to save for a future tax increase. But people do not live forever and do not care about taxes levied after their death. It should be noticed that REH does not mean that any countercyclical efforts will fail, but outlines the necessary conditions for that failure and, subsequently, for their success at the same time.

\section{Unit roots, cointegration and Granger causality}

Firstly, we examine the time series for unit roots. This is important because it helps us to understand whether several shocks have permanent or transitory effects. For ex-

ample, for a country's intertemporal solvency condition to hold, the change in the country's obligations to the rest of the world (i.e. its CAD) must be stationary. Economic time series can be categorised according to their type of trend: (a) stationary processes with deterministic (linear or quadratic) trends, in which shocks have transitory effects, and (b) processes with stochastic trends (or unit roots), in which shocks have permanent effects.

The present analysis employs two standard tests for unit roots. The first one is the augmented Dickey-Fuller (ADF) test, which removes all the structural effects from the time series and then tests the null hypothesis of a unit root. The ADF regression may include deterministic components, such as a constant or a linear trend. The second test is the Kwiatkowski-Phillips-Schmidt-Shin (KPSS) test, which tests the null hypothesis of stationarity. In this test, the absence of a unit root implies trend stationarity. This means that the shock is transitory and the time series will converge again towards the growing mean, which is not affected by the shock. On the other hand, a unit root process has a permanent impact on the mean. This implies that there is no convergence over time.

Moving to cointegration, theory often suggests that certain pairs of economic variables should be linked by a long-run economic relationship. For example, two or more individual 
Table 1

ADF unit root test results

\begin{tabular}{|c|c|c|c|}
\hline Country & Variable & Model & $p$-value \\
\hline \multirow[t]{6}{*}{ Portugal } & \multirow[t]{3}{*}{ CAD } & Constant, no trend & 0.6356 \\
\hline & & Constant and trend & 0.6261 \\
\hline & & No constant, no trend & 0.0867 \\
\hline & \multirow[t]{3}{*}{ BD } & Constant, no trend & 0.5724 \\
\hline & & Constant and trend & 0.9066 \\
\hline & & No constant, no trend & 0.3114 \\
\hline \multirow[t]{6}{*}{ Italy } & \multirow[t]{3}{*}{ CAD } & Constant, no trend & 0.6432 \\
\hline & & Constant and trend & 0.7943 \\
\hline & & No constant, no trend & 0.1715 \\
\hline & \multirow[t]{3}{*}{$\mathrm{BD}$} & Constant, no trend & 0.1602 \\
\hline & & Constant and trend & 0.4451 \\
\hline & & No constant, no trend & 0.5038 \\
\hline \multirow[t]{6}{*}{ Greece } & \multirow[t]{3}{*}{ CAD } & Constant, no trend & 0.9113 \\
\hline & & Constant and trend & 0.7576 \\
\hline & & No constant, no trend & 0.3637 \\
\hline & \multirow[t]{3}{*}{$\mathrm{BD}$} & Constant, no trend & 0.6832 \\
\hline & & Constant and trend & 0.9180 \\
\hline & & No constant, no trend & 0.2937 \\
\hline \multirow[t]{6}{*}{ Spain } & \multirow[t]{3}{*}{$C A D$} & Constant, no trend & 0.7311 \\
\hline & & Constant and trend & 0.7244 \\
\hline & & No constant, no trend & 0.1967 \\
\hline & \multirow[t]{3}{*}{$\mathrm{BD}$} & Constant, no trend & 0.4288 \\
\hline & & Constant and trend & 0.7631 \\
\hline & & No constant, no trend & 0.2030 \\
\hline
\end{tabular}

Notes: The unit root hypothesis cannot be rejected in any case at the $5 \%$ level of significance.

Source: Authors' own estimations.

series may have unit roots (i.e. they are first-order integrated or I(1)), but a vector of coefficients exists and forms a stationary linear combination of them. More formally, time series $x_{t}$ and $y_{t}$ are said to be cointegrated if there exists a parameter $a$ such that $u_{t}=y_{t}-a x_{t}$ is a stationary process. In the following analysis, three cointegration tests are employed. The first one is the Engle-Granger test, which is a residual-based test and runs a static regression (after first having verified that $y_{t}$ and $x_{t}$ are both $\left.l(1)\right) y_{t}=\theta^{\prime} x_{t}+e_{t}$. The second test is the Phillips-Ouliaris test, which is also a residual-based test and an improvement of the EngleGranger test. The third test is the Johansen test, which has the advantage of allowing to test for cointegration without choosing the dependent variable on the test regression.

Finally and regarding causality, the Granger causality test determines whether one time series is useful in forecast-
Table 2

KPSS unit root test results

\begin{tabular}{|c|c|c|c|}
\hline Country & Variable & Model & LM-stat. \\
\hline \multirow[t]{4}{*}{ Portugal } & \multirow[t]{2}{*}{ CAD } & Constant, no trend & $0.7869^{\star}$ \\
\hline & & Constant and trend & $0.2134^{*}$ \\
\hline & \multirow[t]{2}{*}{$\mathrm{BD}$} & Constant, no trend & 0.2105 \\
\hline & & Constant and trend & $0.1839^{*}$ \\
\hline \multirow[t]{4}{*}{ Italy } & \multirow[t]{2}{*}{ CAD } & Constant, no trend & 0.3165 \\
\hline & & Constant and trend & $0.2619^{*}$ \\
\hline & \multirow[t]{2}{*}{$\mathrm{BD}$} & Constant, no trend & $0.5000^{*}$ \\
\hline & & Constant and trend & $0.5000^{*}$ \\
\hline \multirow[t]{4}{*}{ Greece } & \multirow[t]{2}{*}{ CAD } & Constant, no trend & $0.6357^{\star}$ \\
\hline & & Constant and trend & $0.3562^{*}$ \\
\hline & \multirow[t]{2}{*}{$\mathrm{BD}$} & Constant, no trend & 0.2297 \\
\hline & & Constant and trend & $0.2309^{*}$ \\
\hline \multirow[t]{4}{*}{ Spain } & \multirow[t]{2}{*}{ CAD } & Constant, no trend & $0.6175^{*}$ \\
\hline & & Constant and trend & $0.2449^{*}$ \\
\hline & \multirow[t]{2}{*}{$\mathrm{BD}$} & Constant, no trend & $0.5575^{\star}$ \\
\hline & & Constant and trend & $0.1470^{*}$ \\
\hline
\end{tabular}

Notes: * denotes rejection of the stationarity hypothesis at the $5 \%$ leve of significance.

Source: Authors' own estimations.

ing another and finds patterns of correlation. However, correlation does not necessarily imply causation. Assuming there are two variables $x$ and $y$, the approach to the question of whether $x$ causes $y$ is to determine how much of the current $y$ can be explained by past values of $y$, and then to investigate whether adding lagged values of $x$ can improve the explanation. The variable $y$ is said to be Granger-caused by $x$ if $x$ helps in the prediction of $y$, or equivalently, if the coefficients on the lagged values of $x$ are statistically significant. The null hypothesis for this test is that the lagged values of $x$ do not explain the variation in $y$.

\section{Data and econometric results}

This article uses data for Portugal, Italy, Greece and Spain from 1999Q1 until 2017Q3, obtained from the Eurostat database. Figure 1 reports $B D$ and $C A D$ as a percentage of GDP for these countries. Table 1 reports the ADF test results and shows that the unit root hypothesis cannot be rejected for both variables at the $5 \%$ significance level. Similar results are obtained from the KPSS test (see Table 2). The stationarity hypothesis is rejected for both variables in almost all cases. Based on the above, there is clear evidence of non-stationarity for both $B D$ and $C A D$ for all four countries. 
Table 3

Engle-Granger and Philips-Ouliaris cointegration test results

\begin{tabular}{|c|c|c|c|c|c|}
\hline \multirow[b]{2}{*}{ Country } & \multirow[b]{2}{*}{$\begin{array}{l}\text { Dependent } \\
\text { variable }\end{array}$} & \multicolumn{2}{|c|}{ Engle-Granger test } & \multicolumn{2}{|c|}{ Philips-Ouliaris test } \\
\hline & & $p$-value & Conclusion & $p$-value & Conclusion \\
\hline \multirow[t]{2}{*}{ Portugal } & $\mathrm{BD}$ & $0.0079^{*}$ & Cointegration & $0.0000^{*}$ & Cointegration \\
\hline & CAD & 0.9083 & $\begin{array}{l}\text { No } \\
\text { cointegration }\end{array}$ & 0.7850 & $\begin{array}{l}\text { No } \\
\text { cointegration }\end{array}$ \\
\hline \multirow[t]{2}{*}{ Italy } & $\mathrm{BD}$ & 0.1729 & $\begin{array}{l}\text { No } \\
\text { cointegration }\end{array}$ & $0.0000^{*}$ & Cointegration \\
\hline & CAD & 0.8562 & $\begin{array}{l}\text { No } \\
\text { cointegration }\end{array}$ & $0.0204^{*}$ & Cointegration \\
\hline \multirow[t]{2}{*}{ Greece } & $\mathrm{BD}$ & $0.0002^{*}$ & Cointegration & $0.0001^{*}$ & Cointegration \\
\hline & CAD & 0.8855 & $\begin{array}{l}\text { No } \\
\text { cointegration }\end{array}$ & $0.0006^{*}$ & Cointegration \\
\hline \multirow[t]{2}{*}{ Spain } & $\mathrm{BD}$ & 0.6623 & $\begin{array}{l}\text { No } \\
\text { cointegration }\end{array}$ & $0.0000^{*}$ & Cointegration \\
\hline & CAD & 0.9572 & $\begin{array}{l}\text { No } \\
\text { cointegration }\end{array}$ & 0.8949 & $\begin{array}{l}\text { No } \\
\text { cointegration }\end{array}$ \\
\hline
\end{tabular}

Notes: The regression model does not include any deterministic terms. The $p$-values are based on the Engle-Granger $t$-statistic. * denotes rejection of the null hypothesis of no cointegration at the $5 \%$ level of significance.

Source: Authors' own estimations.

Moving to cointegration test results, Table 3 reports the results of the Engle-Granger and Philips-Ouliaris tests, and Table 4 presents the results of the Johansen test. The results of these two tables are mixed. However, it seems that there is evidence of cointegration between BD and CAD for Greece and Italy but not for Portugal and Spain. Regarding Granger causality, the test results are reported in Table 5. There is evidence of bi-directional Granger causality between $C A D$ and $B D$ for Italy and Spain. For Greece, CAD Granger causes BD, while the opposite does not hold. Finally, there is no evidence of Granger causality for Portugal.

\section{Discussion and policy implications}

Relating the results of the above analysis to policymaking, we can split the sample countries into two groups. The first group consists of Portugal and Spain, showing weak evidence that $C A D$ and $B D$ are cointegrated in the long run. An increase in $B D$ will be totally offset by changes in private savings and, thus, there will be no impact on CAD, validating the REH for these two countries. This implies that consumers in Portugal and Spain are forwardlooking in their expenditure decisions. Tax cuts imply a delayed pressure to raise taxes as governments will need to fill the budget gap due to the initial tax cuts. So, rational
Table 4

Johansen cointegration test results

\begin{tabular}{lllll} 
Country & Model & Trace & $\begin{array}{c}\text { Maximum } \\
\text { eigenvalue }\end{array}$ & Conclusion \\
\hline Portugal & $\begin{array}{l}\text { Intercept (no } \\
\text { trend) in CE - no } \\
\text { intercept in VAR }\end{array}$ & 0.5118 & 0.5495 & No cointegration \\
\cline { 2 - 5 } & $\begin{array}{l}\text { Intercept (no } \\
\text { trend) in CE and } \\
\text { test VAR }\end{array}$ & 0.2974 & 0.5504 & No cointegration \\
\hline Italy & $\begin{array}{l}\text { Intercept (no } \\
\text { trend) in CE - no } \\
\text { intercept in VAR }\end{array}$ & 0.5683 & 0.4086 & No cointegration \\
\cline { 2 - 6 } & $\begin{array}{l}\text { Intercept (no } \\
\text { trend) in CE and } \\
\text { test VAR }\end{array}$ & 0.2676 & 0.2796 & No cointegration \\
\hline Greece & $\begin{array}{l}\text { Intercept (no } \\
\text { trend) in CE - no } \\
\text { intercept in VAR }\end{array}$ & 0.1218 & $0.0459^{*}$ & Cointegration \\
\cline { 2 - 6 } $\begin{array}{l}\text { Intercept (no } \\
\text { trend) in CE and } \\
\text { test VAR }\end{array}$ & $0.0363^{*}$ & $0.0314^{*}$ & Cointegration \\
\hline Spain & $\begin{array}{l}\text { Intercept (no } \\
\text { trend) in CE - no } \\
\text { intercept in VAR }\end{array}$ & 0.2898 & 0.2605 & No cointegration \\
\cline { 2 - 5 } $\begin{array}{l}\text { Intercept (no } \\
\text { trend) in CE and } \\
\text { test VAR }\end{array}$ & 0.1049 & 0.1733 & No cointegration \\
\hline & & & & \\
\hline
\end{tabular}

Notes: The trace statistic test tests the null hypothesis of no cointegration $\left(H_{0}: r=0\right)$ against the alternative hypothesis of cointegration $\left(H_{1}: r>0\right)$. The maximum eigenvalue statistic test tests null hypothesis that there are $r$ cointegrating relations against the alternative hypothesis that there are $r+1$ cointegrating relations. The numbers reported are $p$-values. * denotes rejection of the null hypothesis of no cointegration at the $5 \%$ level of significance.

Source: Authors' own estimations.

consumers will put the additional disposable income into savings, and consumption will not rise.

This has a direct impact on the way that policymakers implement economic measures. Especially during the last decade when both countries were harmed by the global financial crisis, there was a political consensus on structural reforms of the labour and product markets, the public sector, the tax and pension systems, and the financial sector. These reforms helped Portugal and Spain to regain access to capital markets and deal with their debt issues quite easily, as their bond yields decreased.

The second group consists of Italy and Greece, for which there is stronger evidence in favour of the $\mathrm{TDH}$ : policy measures taken in order to reduce CAD could partially improve public finances. However, as these two countries face very high debt-to-GDP ratios, structural reforms in the public administration, the labour and capital markets, 
Table 5

\section{Granger causality test results}

\begin{tabular}{|c|c|c|c|}
\hline Country & $\begin{array}{l}\text { Null hypothesis } \\
(\mathrm{HO})\end{array}$ & Lags & $p$-value \\
\hline \multirow[t]{2}{*}{ Portugal } & $\begin{array}{l}\text { CAD does not } \\
\text { Granger cause } \\
\text { BD }\end{array}$ & 5 & 0.1100 \\
\hline & $\begin{array}{l}\text { BD does not } \\
\text { Granger cause } \\
\text { CAD }\end{array}$ & 5 & 0.4224 \\
\hline \multirow[t]{2}{*}{ Italy } & $\begin{array}{l}\text { CAD does not } \\
\text { Granger cause } \\
\text { BD }\end{array}$ & 6 & $0.0440^{\prime}$ \\
\hline & $\begin{array}{l}\text { BD does not } \\
\text { Granger cause } \\
\text { CAD }\end{array}$ & 6 & $0.0000^{\prime}$ \\
\hline \multirow[t]{2}{*}{ Greece } & $\begin{array}{l}\text { CAD does not } \\
\text { Granger cause } \\
\text { BD }\end{array}$ & 4 & 0.0016 \\
\hline & $\begin{array}{l}\text { BD does not } \\
\text { Granger cause } \\
\text { CAD }\end{array}$ & 4 & 0.0916 \\
\hline \multirow[t]{2}{*}{ Spain } & $\begin{array}{l}\text { CAD does not } \\
\text { Granger cause } \\
\text { BD }\end{array}$ & 6 & 0.0092 \\
\hline & $\begin{array}{l}\text { BD does not } \\
\text { Granger cause } \\
\text { CAD }\end{array}$ & 6 & 0.0002 \\
\hline
\end{tabular}

Notes: The number of lags was selected using the Akaike information criterion. * denotes rejection of the null hypothesis of no cointegration at the $5 \%$ level of significance.

Source: Authors' own estimations.

and the tax and insurance systems are necessary in order to improve their competitiveness, current account and thus, their budget balance. Investments in new technology, innovations in exporting sectors and tax cuts on selected industries will also help. Unfortunately, there was no political consensus during the crisis regarding the promotion of these reforms. Due to political costs, policymakers dealt with issues only partially, leading to a delayed access to capital markets and to higher bond yields than those of Portugal and Spain. Especially the Greek current account is slightly deteriorating, confirming the above arguments.

\section{References}

Abell, J. D. (1990), Twin deficits during the 1980's: an empirical investigation, Journal of Macroeconomics, 12, 81-96.

Afonso, A. (2008), Euler testing Ricardo and Barro in the EU, Economics Bulletin, 5, 1-14.

Akdogan, I. U. and H. K. Geldi (2013), Revisiting the twin deficit hypothesis for the economies of Europe, Journal of European Theoretical and Applied Studies, 1, 53-65.

Antzoulatos, A. A. (2011), Greece in 2010: a tragedy without(?) catharsis, International Advances in Economic Research, 17, 241-257.
Bachman, D. D. (1992), Why is the US current account deficit so large: evidence from vector auto regressions, Southern Economic Journal, $59,232-240$.

Barro, R. (1974), Are government bonds net wealth?, Journal of Political Economy, 82, 1095-1117.

Bartolini, L. and A. Labiri (2006), Twin deficits, twenty years later, Current Issues in Economics and Finance, 12(7), 1-7.

Bernheim, B. (1987), Ricardian equivalence: an evaluation of theory and evidence, NBER Macroeconomics Annual, 263-304.

Bitzis, G., J. M. Paleologos and C. Papazoglou (2008), The determinants of the Greek current account deficit: the EMU experience, Journal of International and Global Economic Studies, 1(1), 105-122.

Blinder, A. S. and R. M. Solow (1973), Does fiscal policy matter?, Journal of Public Economics, 2, 319-337.

Cardoso, M. and R. Doménech (2011), On Ricardian Equivalence and Twin Divergence, in J. E. Boscá, R. Doménech, J. Ferri and J. Varela (eds.), The Spanish Economy, Palgrave Macmillan.

Cavallo, M. (2005), Government consumption expenditures and the current account, Federal Reserve Bank of San Francisco Working Paper, 2005-03.

Chinn, M. and E. S. Prasad (2000), Medium-term determinants of current accounts in industrial and developing countries: an empirical exploration, Journal of International Economics, 59, 47-76.

Deltoro, S. L. and M. Camarero (2015), Twin deficits hypothesis for European countries, University of Jaume I.

Enders, W. and B. S. Lee (1990), Current account and budget deficits: twins or distant cousins?, Review of Economics and Statistics, 72, 373381.

Erceg, C., L. Guerrieri and C. Gust (2005), Expansionary fiscal shocks and the trade deficit, Board of Governors of the Federal Reserve System, International Finance Discussion Papers, 825.

Feldstein, M. (1992), The budget and trade deficits aren't really twins, NBER Working Papers, 3966.

Forte, F. and C. Magazzino (2013), Twin deficits in European countries, International Atlantic Economic Society, 19, 289-310.

Gale, W. G. and P. R. Orszag (2003), Economic effects of sustained budget deficits, National Tax Journal, 56, 463-485.

Kalou, S. and S.-M. Paleologou (2012), The twin deficits hypothesis: revisiting an EMU country, Journal of Policy Modeling, 34, 230-241.

Kearney, C. and M. Monadjemi (1990), Fiscal policy and current account performance: international evidence on the twin deficits, Journal of Macroeconomics, 12, 197-219.

Khalid, A. M. and T. W. Guan (1999), Causality tests of budget and current account deficits: cross-country comparisons, Empirical Economics, 24, 389-402.

Kim, S. and N. Roubini (2008), Twin deficit or twin divergence? Fiscal policy, current account, and real exchange rate in the U.S., Journal of International Economics, 74, 362-383.

Kosteletou, N. E. (2013), Financial integration, euro and the twin deficits of southern eurozone countries, Panoeconomicus, 60, 161-178.

Kouassi, E., M. Mougoué and K. O. Kymn (2004), Causality tests of the relationship between the twin deficits, Empirical Economics, 29, 503525.

Leachman, L. and B. Francis (2002), Twin deficits: apparition or reality?, Applied Economics, 34, 1121-1132.

Magazzino, C. (2012), The twin deficits phenomenon: evidence from Italy, Journal of Economic Cooperation and Development, 33, 65-80.

Mukhtar, T., M. Zakaria and M. Ahmed (2007), An empirical investigation for the twin deficits in Pakistan, Journal of Economic Cooperation, 28, 63-80.

Nickel, C. and I. Vansteenkiste (2008), Fiscal policies, the current account and Ricardian equivalence, European Central Bank Working Paper, 935.

Normandin, M. (1999), Budget deficit persistence and the twin deficits hypothesis, Journal of International Economics, 49, 171-193.

Piersanti, G. (2000), Current account dynamics and expected future budget deficits: some international evidence, Journal of International Money and Finance, 19, 255-271.

Reitschuler, G. and J. Crespo Cuaresma (2004), Ricardian equivalence revisited: evidence from OECD countries, Economics Bulletin, 5, 1-10.

Vamvoukas, G. (1999), The twin deficits phenomenon: evidence from Greece, Applied Economics, 31, 1093-1100. 